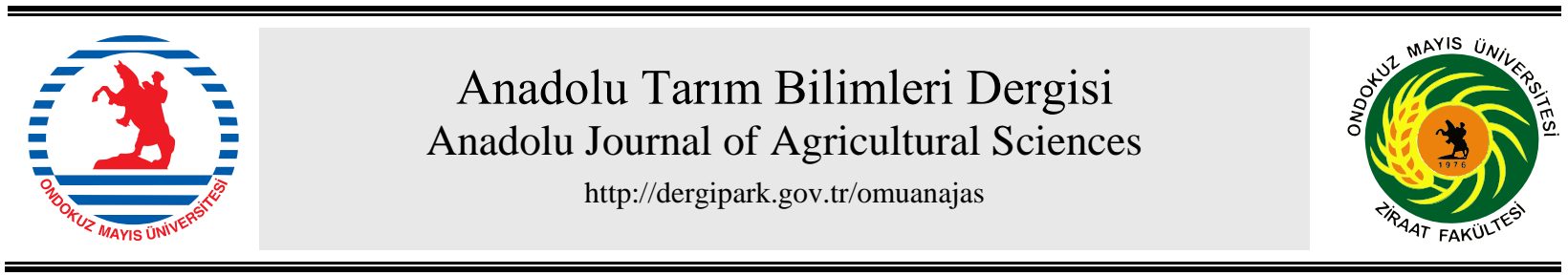

Araştırma/Research

Anadolu Tarım Bilim. Derg./Anadolu J Agr Sci, 36 (2021)

ISSN: 1308-8750 (Print) 1308-8769 (Online)

doi: 10.7161/omuanajas.812575

\title{
Zonguldak İlinde Meyve Üreticilerinin Kimyasal Gübre ve Tarım İlacı Kullanımına Yönelik Çevresel Duyarlılıkları
}

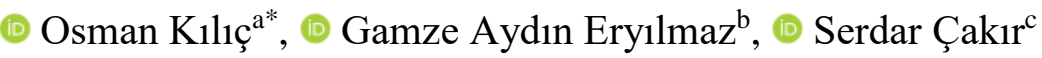 \\ ${ }^{a}$ Ondokuz Mayıs Üniversitesi, Ziraat Fakültesi, Tarım Ekonomisi Bölümü, Samsun, Türkiye \\ ${ }^{b}$ Ondokuz Mayıs Üniversitesi, Samsun Meslek Yüksekokulu, Park ve Bahçe Bitkileri Bölümü, Samsun, Türkiye \\ ${ }^{c}$ Çaycuma İlçe Tarım ve Orman Müdürlüğü, Zonguldak, Türkiye \\ *Sorumlu yazar/corresponding author: okilic@omu.edu.tr
}

\begin{abstract}
ÖZET
Geliș/Received 27/10/2020 Kabul/Accepted 13/11/2020

Konvansiyonel meyve yetiştiriciliğinde kimyasal gübre ve tarım ilacı kullanımı verimi artırmakta, ancak yoğun ve bilinçsiz uygulamalar, insan başta olmak üzere doğadaki bütün varlıkları olumsuz etkilemektedir. $\mathrm{Bu}$ araştırmanın amacı, Zonguldak ilinde konvansiyonel meyve yetiştiriciliği yapan işletmelerde kimyasal gübre ve ilaç kullanımından kaynaklanan çevre sorunlarına yönelik üretici duyarlılığının belirlenmesidir. Üreticilerin kimyasal gübre ve ilaç kullanımına yönelik duyarlılıkları; uygulama öncesi, uygulama esnası ve uygulama sonrasındaki tutum ve davranışlarına göre üç aşamada değerlendirilmiştir. Araştırmada, tabakalı tesadüfi örnekleme yöntemiyle belirlenen 125 meyve üreticisiyle anket yapılmıştır. Araştırma sonuçlarına göre üreticilerin en önemli görüşünün, ürün verimini koruyacak şekilde kimyasal gübre ve ilaç kullanımını azaltmak istemeleri olduğu tespit edilmiştir. Ayrıca üreticilerin, toprak analizi yaptırma ve entegre mücadele yöntemlerini uygulamada çok fazla istekli olmadıkları ortaya konulmuştur. Araştırmadan elde edilen diğer önemli bir sonuç ise, gübreleme ve ilaçlama sonrası boş ambalajların imha edilmesi sorununun, üretici ve tüketici sağlığı ile çevrenin korunması açısından çözüme kavuşturulması gereken konular arasında yer almasıdır. Bu sonuçlar; bilinçli kimyasal gübre ve ilaç kullanımı, kimyasal mücadele dışındaki yöntemlerin uygulanabilirliği ve atık yönetimiyle ilgili konulara yönelik eğitim ve yayım çalışmalarını öncelikli hale getirmektedir.
\end{abstract}

\section{Environmental Sensitivity of Fruit Producers Toward Chemical Fertilizer and Pesticide Use in Zonguldak Province}

\section{ABSTRACT}

The use of chemical fertilizers and pesticides in conventional fruit growing increases yield, but intensive and unconscious practices negatively affect all entities in nature, especially human. The aim of this research is to determine the sensitivity of producers to environmental problems caused by the use of chemical fertilizers and pesticides in conventional fruit growing farms in Zonguldak province. The sensitivity of the producers towards the use of chemical fertilizers and pesticides was evaluated considering their attitudes in three stages of application; before, during and after application. In the research, a survey was conducted with 125 fruit producers determined by the stratified random sampling method. According to the results of the research, it has been determined that the most important opinion of the producers is that they want to reduce the use of chemical fertilizers and pesticides in a way that preserves product yield. In addition, it has been revealed that the producers are not very willing to conduct soil analysis and apply integrated control methods. Another important result obtained from the research is that the problem of disposing of empty packages after fertilization and spraying is among the issues that need to be resolved in terms of producer and consumer health and protection of the environment. These results prioritize training and extension activities on conscious use of chemical fertilizers and pesticides, applicability of methods other than chemical control, and waste management.
Anahtar Sözcükler: Meyve yetiştiriciliği Kimyasal gübre Tarim ilaci Çevresel duyarlılık Üretici tutum ve davranış1
Keywords:

Fruit growing

Chemical fertilizer

Pesticide

Environmental

sensitivity

Producers' attitude and behavior

(c) OMU ANAJAS 2021 


\section{Giriş}

Tarım; besin ihtiyacını karşılamanın yanı sıra, özellikle az gelişmiş ve gelişmekte olan ülkeler için ekonominin öncü sektörü olma özelliği nedeniyle daima önemini korumaktadır. Dünya nüfusundaki hızlı artışın etkisiyle, artan gıda ihtiyacının karşılanması için gerekli tedbirler alınmadığı takdirde, bu ihtiyacın ileriki yıllarda mevcut üretim olanaklarıyla karşılanamayacağı düşünülmektedir. Dolayısıyla gelecek nesillere ait gıda talebinin karşılanması, tarımsal ürünlerde verimliliğin artırılmasını kaçınılmaz kılmaktadır. Tarımsal ürünlerde verim ve kaliteyi artırmanın yolu, modern tarımsal tekniklerin ve girdilerin kullanılmasından geçmektedir. Ancak uzun yıllar üretimi artırmayı hedefleyen bu anlayış, daha fazla verim alabilmek için kimyasal gübre ve ilaç kullanımını zorunlu hale getirmiştir. $\mathrm{Bu}$ süreçte gelişmiş ülkeler, üreticilerin geçimlerini sağlayacak geliri teminat altına almanın yanı sıra, gelecek nesillerin gıda ihtiyacını tehlikeye düşürmemek ve çevre sorunlarına yol açmamak için, tarımsal girdilerin çevreyle daha uyumlu bir şekilde kullanılmasını öncelikli hedef kabul etmişlerdir. Az gelişmiş ve gelişmekte olan ülkelerde ise bundan farklı olarak, tarım işletmeleri önemli yapısal problemlere sahip oldukları için, tarım ve çevre ilişkilerinin henüz tam olarak kurulduğu söylenemez.

Tarım toprakları; besin maddelerinin bitkiler tarafindan alınması, yıkanması ve erozyona uğraması sonucu zamanla fakirleşmektedir. Bu nedenle tarımsal üretimin en önemli kaynağı olan toprak, gübreleme ve diğer tarımsal işlemlerle daha verimli hale getirilmeye çalışılmaktadır. Dolayısıyla gübreleme, toprağın verimliliğini sürdürebilmesi için bitkiler tarafindan kullanılan besin maddelerinin toprağa takviye edilmesi bakımından önemlidir (Sönmez ve ark., 2008). Tarım ilaçları ise zararlı organizmaları engellemek, kontrol altına almak ya da zararlarını azaltmak için kullanılan maddelerden oluşan karışımlardır (Özcan ve Tongur, 2019). Tarımda verimliliğin artırılması, girdilerin tekniğine uygun şekilde kullanılmasına bağlıdır. Bitkiler tarafından kullanılan gübreden geriye kalanı, yer altı ve yüzey sularına karışarak insan, bitki ve hayvan sağlığını tehdit etmektedir. Ayrıca artan gübre ihtiyacını karşılamak için kurulan üretim tesislerinden, çevreye yayılan atık sular da dikkate alındığında sorunun ne kadar kritik boyutta olduğu görülecektir (Atılgan ve ark., 2007). Tarımsal mücadelenin, olası sağlık risklerini ve korunma yollarını bilerek, tarımsal ekosistemdeki tüm canlıları korumayı dikkate alacak şekilde uygun metotlarla yapılması gerekir. Tarım ilaçları önerilen metot ve dozda uygulanmaz ise, tarımsal ekosistem yoğun ilaç kullanımının neden olduğu kalıntılarla kirlenecektir. Bu kirlilik, besin zinciri ve benzeri yollarla canlılara ulaşacak ve ciddi sağlık riskleri oluşturacaktır (Akar ve Tiryaki, 2018).

Türkiye; sahip olduğu iklim koşulları, verimli toprak yapısı ve sulama potansiyeli nedeniyle bütün bölgelerde meyve yetiştiriciliğinin yapılmasına uygun bir ekolojiye sahiptir. Meyve yetiştiriciliğinde verimi artırmak için, yeterli gübre kullanımı ve uygun sulama yöntemleri gibi uygulamaların yanında hastalık, zararlı ve yabancı otlarla da etkili mücadelenin yapılması zorunludur (Erbek ve ark., 2018). Ancak birim alandan daha fazla ürün elde etmek amacıyla yoğun dozda gübre uygulamak, ayrıca hastalık ve zararlılarla mücadelenin erken aşamalarında dahi çoğu zaman tek çözüm yolu olarak ilaçlamayı görmek doğru bir yaklaşım değildir (Peker, 2012). Kaldı ki gereğinden fazla uygulanan kimyasalların, insan sağlığı ve çevreye uzun vadede öngörülen olumsuz etkileri küresel nitelikte olup, bu durum ciddi sosyal ve ekonomik sorunları beraberinde getirmektedir. Doğal kaynakların tahrip olmasıyla birlikte, tarımsal ürünlerde dışa bağımlılık, kırsal alandan kentlere göç, kırsal toplum özelliğinin yok olması, kırsal ve kentsel nüfus dengesizliğinin artması gibi başlıca sorunlar ortaya çıkmaktadır (Eryılmaz ve Kılıç, 2018).

Türkiye'de, tarımsal ürünlerde kimyasal gübre ve ilaç kullanımı ile üreticilerin çevre sorunlarına karşı duyarlılıklarını ele alan birçok araştırma yapılmıştır (Kurtaslan ve ark., 2000; Kızılaslan ve Kızılaslan, 2005; Günden ve Miran, 2008; Peker, 2012; Kızıloğlu ve Kızılaslan, 2017; Akar ve Tiryaki, 2018; Aydın ve ark., 2019; Bayraktar ve Boz, 2020; Sayın ve ark., 2020). Tarımsal girdilerin yoğun uygulandığı meyve yetiştiriciliğinde ise, kimyasal gübre ve ilaç kullanımına yönelik üretici duyarlılığını ele alan araştırmaların sayısında son yıllarda artış vardır (Oğuz ve ark., 2000; Demircan ve Yılmaz, 2005; Akbaba, 2010; Çelik ve Karakaya, 2017; Erdoğan ve ark., 2017; Erbek ve ark., 2018; Kılıç ve ark., 2018; Dilmen ve ark., 2020). Yapılan araştırmalarda, üretici algısının yoğun ve bilinçsiz kullanılan gübre ve ilaçların çevreyi olumsuz etkilediği yönünde olduğuna, biyolojik mücadele yöntemlerinin ise üreticiler tarafından yeterince bilinmediğine işaret edilmektedir. Ayrıca araştırmalarda, giderek yaygınlaşan çevre dostu tarımsal üretim tekniklerinin benimsenmesi ve uygulanmasıyla ilgili önemli bilgilere de yer verilmektedir. $\mathrm{Bu}$ araştırmalar; tarımsal faaliyetlerden kaynaklanan çevresel sorunların çözümüne yönelik üretici bilincinin ve duyarlılığının geliştirilmesine, çevre sorunlarına yönelik politikaların oluşturulmasına ve gerekli önlemlerin alınmasına katkı sağlaması açısından büyük önem taşımaktadır.

Araştırmanın yapıldığı Zonguldak ilinde, 2019 yılı itibariyle 483204 dekar olan tarım arazisi içinde \%58.03 ile en yüksek pay meyve yetiştiriciliğine aittir. İldeki meyve arazisinin önemli bir kısmını ise findık arazisi (\%91.91) oluşturmakta, bunu ceviz arazisi (\%3.64) ve elma arazisi (\%1.11) izlemektedir. Bunların dişında kiraz, armut, çilek, kestane, kivi, erik, vişne, ayva, dut, şeftali, üzüm ve böğürtlen yetiştiriciliği yapılmakla birlikte, bunların toplam meyve arazisi içindeki payı \%3.34'tür (TÜIK, 2020). Bu araştırmanın amacı, konvansiyonel meyve üreticilerinin kimyasal gübre ve tarım ilaçlarının uygulama öncesi, uygulama süreci ve uygulama sonrasındaki çevresel 
duyarlılıklarının tespit edilmesidir. Araştırmayla, gübre ve ilaçların temin edilmesi, saklanması, güvenli kullanımı ve kullanım sonrasındaki üretici tutum ve davranışlarını ortaya koyarak, çevresel sorunlara yönelik çözüm önerilerine dikkat çekilmesi amaçlanmıştır. Araştırma sonuçlarının; üreticiler açısından tarımsal üretimde kârlılığın, tüketiciler açısından güvenilir gıdanın, tarımsal açıdan ise sürdürülebilirliğin sağlanması için gerekli altyapının oluşturulmasına ve uygulamaya dönük düzenlemelerin yapılmasına katkı sağlaması beklenmektedir.

\section{Materyal ve Yöntem}

Araştırmanın materyalini, konvansiyonel meyve yetiştiriciliği yapan ve çiftçi kayıt sistemine kayıtlı işletmelerle 2020 yılında yapılan anketler oluşturmaktadır. Araştırmada, örnekleme birimi olarak meyve arazisi büyüklüğü esas alınmıştır. İşletmeler; 1-6 dekar, 7-13 dekar, 14 dekar ve daha fazla meyve arazisine sahip olanlar şeklinde üç gruba ayrılmıştır. Daha sonra anket yapılan işletme sayısı, tabakalı tesadüfi örnekleme yöntemiyle 125 olarak belirlenmiştir (Yamane, 1967). Oransal dağılıma göre anket yapılan işletme sayısı; birinci grupta 57, ikinci grupta 37 ve üçüncü grupta 31 olarak tespit edilmiştir. Veriler, işletme büyüklük grupları ve işletmeler ortalamasına göre değerlendirilmiştir.

Anket formunun birinci bölümü; işletme yöneticisi konumundaki üreticilere ait bilgileri, işletmeye ait sosyoekonomik özellikleri, işletmelerdeki arazi mülkiyet durumunu ve tasarruf şekillerini kapsamaktadır. İkinci bölüm ise üreticilerin kimyasal gübre ve tarım ilacı kullanımı konusunda; uygulama öncesinde, uygulama esnasında ve uygulama sonrasındaki çevresel duyarlılıklarının tespit edilmesine yönelik olarak hazırlanmıştır. Üreticilerin kimyasal gübre ve ilaç kullanımına ilişkin duyarlılıklarındaki önem sırası, 5'li likert tipi şeklindeki sorulara verdikleri cevaplar doğrultusunda hesaplanan ortalama skora göre belirlenmiştir (Hiçbir zaman: 1, nadiren: 2, ara sira: 3, genellikle: 4 , her zaman: 5).

Araştırmada; yaş, eğitim, tarımsal deneyim, tarım dışı gelir, aile nüfusu, büyükbaş hayvan sayısı, arazi mülkiyeti ve arazi tasarruf şekilleri açısından işletme büyüklük grupları arasındaki farklılığın test edilmesinde varyans analizinden yararlanılmıştır. Tek yönlü varyans analizinde, işletme büyüklük grupları arasındaki farklılıkların görülebilmesi için, Post-Hoc çoklu karşılaştırma testlerinden Tukey testi uygulanmıştır. Üreticilerin kimyasal gübre ve ilaç kullanımına yönelik çevresel duyarlılıkları Kruskal-Wallis H testiyle değerlendirilmiş, gruplar arasındaki farklılığın test edilmesinde ise Mann-Whitney U testi kullanılmıştır.

\section{Bulgular ve Tartışma}

Anket yapılan işletme yöneticilerinin cinsiyete göre dağılımları incelendiğinde, üç işletme büyüklük grubunda da çoğunluğu erkeklerin oluştuğu görülmektedir. İşletme büyüklük grupları arttıkça işletme yöneticilerinin yaş ortalaması düşmekte, eğitim $(\mathrm{P}<0.01)$ ve tarımsal deneyim süresi $(\mathrm{P}<0.01)$ ise artmaktadır (Çizelge 1$)$.

Çizelge 1. İşletme yöneticisine ve işletmeye ait özellikler Table 1. Characteristics related to farm manager and farm

\begin{tabular}{|c|c|c|c|c|}
\hline & 1. grup & 2. grup & 3. grup & $\begin{array}{l}\text { İşletmeler } \\
\text { ortalamas1 }\end{array}$ \\
\hline \multicolumn{5}{|l|}{ Yöneticiye ait özellikler } \\
\hline \multicolumn{5}{|l|}{ Cinsiyet (\%) } \\
\hline Kadın & 14.04 & 13.51 & 6.45 & 12.00 \\
\hline Erkek & 85.96 & 86.49 & 93.55 & 88.00 \\
\hline Yaş (yıl) & 53.67 & 54.43 & 51.32 & 53.31 \\
\hline Eğitim $(y 11)^{* * *}$ & $6.21^{\mathrm{a}}$ & $8.03^{\mathrm{b}}$ & $9.55^{\mathrm{b}}$ & 7.58 \\
\hline Tarımsal deneyim $(\mathrm{y} 1 \mathrm{l})^{* * *}$ & $10.32^{\mathrm{a}}$ & $13.08^{\mathrm{b}}$ & $18.87^{\mathrm{c}}$ & 13.26 \\
\hline \multicolumn{5}{|l|}{ Sosyal güvence (\%) } \\
\hline SSK & 61.40 & 59.46 & 58.06 & 60.00 \\
\hline Bağ-Kur & 26.32 & 21.62 & 16.13 & 22.40 \\
\hline Emekli sandığı & 12.28 & 18.92 & 25.81 & 17.60 \\
\hline Tarım dışı gelir (TL/yıl) & 44120.00 & 41150.27 & 52250.32 & 45257.28 \\
\hline \multicolumn{5}{|l|}{ İşletmeye ait özellikler } \\
\hline Aile nüfusu (kişi) & 3.44 & 3.65 & 4.29 & 3.71 \\
\hline \multicolumn{5}{|l|}{ Üretim faaliyeti (\%) } \\
\hline Bitkisel üretim & 77.19 & 83.78 & 90.32 & 82.40 \\
\hline Bitkisel üretim + Hayvancılık & 22.81 & 16.22 & 9.68 & 17.60 \\
\hline Büyükbaş hayvan sayısı (baş) & 0.95 & 0.62 & 0.26 & 0.68 \\
\hline
\end{tabular}


İşletme yöneticilerinin tamamı sosyal güvenceye sahip olup, işletmeler ortalamasına göre SSK, Bağ-Kur ve emekli sandığına bağlı olanların oranı sirasıyla \%60, \%22.40 ve \%17.60'dır. Anket yapılan birinci gruptaki işletmelerde aile nüfusu mevcudu ortalama 3.44 kişi olup, işletme büyüklük gruplarına göre nüfus artmaktadır. Bitkisel üretimle birlikte, sınırlı sayıda büyükbaş hayvanı olan ve büyük ölçüde aile tüketimine yönelik üretim yapan işletmeler de vardır. Büyükbaş hayvan sayısı işletme büyüklük gruplarına göre azalmakta, işletmeler ortalamasına göre 0.68 baş olmaktadır (Çizelge 1).

İncelenen birinci gruptaki işletmelerde arazi varlığı ortalama 5.69 dekar, ikinci ve üçüncü grupta 11.92 dekar ve 23.88 dekardır $(\mathrm{P}<0.01)$. İşletmeler ortalamasına göre 12.05 dekar olan işletme arazisinin \%96.68’i mülk, geriye kalanı kiralanan araziden oluşmaktadır. İşletmelerde yetiştirilen çok sayıda meyve çeşidi bulunmakla birlikte, işletmeler ortalamasına göre fındık toplam arazinin \%67.97'si kadardır. İşletme arazisi içindeki payı yüksek olan diğer meyve çeşitleri ise \%9.71 ile ceviz, \%3.16 ile armut ve \%2.24 ile elmadır. Fındık $(\mathrm{P}<0.01)$ ve ceviz $(\mathrm{P}<0.01)$ arazisi büyüklüğü açısından, işletme büyüklük grupları arasında istatistiki olarak anlamlı farklılık vardır (Çizelge 2).

Çizelge 2. Arazi mülkiyeti ve kullanım durumu

Table 2. Land ownership and usage status

\begin{tabular}{|c|c|c|c|c|c|c|c|c|}
\hline & \multicolumn{2}{|c|}{ 1. grup } & \multicolumn{2}{|c|}{ 2. grup } & \multicolumn{2}{|c|}{ 3. grup } & \multicolumn{2}{|c|}{$\begin{array}{l}\text { İşletmeler } \\
\text { ortalamas1 }\end{array}$} \\
\hline & (da) & $(\%)$ & (da) & $(\%)$ & (da) & $(\%)$ & (da) & $(\%)$ \\
\hline \multicolumn{9}{|l|}{ Arazi mülkiyet durumu } \\
\hline Mülk arazi*** & $5.14^{\mathrm{a}}$ & 90.33 & $11.87^{\mathrm{b}}$ & 99.58 & $23.35^{c}$ & 97.78 & 11.65 & 96.68 \\
\hline Kiralanan arazi & 0.55 & 9.67 & 0.05 & 0.42 & 0.53 & 2.22 & 0.40 & 3.32 \\
\hline İşletme arazisi $* * *$ & $5.69^{\mathrm{a}}$ & 100.00 & $11.92^{\mathrm{b}}$ & 100.00 & $23.88^{c}$ & 100.00 & 12.05 & 100.00 \\
\hline \multicolumn{9}{|l|}{ Arazi tasarruf şekli } \\
\hline Find1k $* * *$ & $2.98^{\mathrm{a}}$ & 52.37 & $6.97^{\mathrm{b}}$ & 58.47 & $19.23^{c}$ & 80.53 & 8.19 & 67.97 \\
\hline Ceviz*** & $0.52^{\mathrm{a}}$ & 9.14 & $0.96^{\mathrm{a}}$ & 8.05 & $2.62^{\mathrm{b}}$ & 10.97 & 1.17 & 9.71 \\
\hline Armut & 0.05 & 0.88 & 0.92 & 7.72 & 0.35 & 1.47 & 0.38 & 3.16 \\
\hline Elma & $0.14^{\mathrm{a}}$ & 2.46 & $0.70^{\mathrm{b}}$ & 5.87 & - & - & 0.27 & 2.24 \\
\hline Kiraz & 0.07 & 1.23 & 0.45 & 3.78 & 0.09 & 0.38 & 0.19 & 1.58 \\
\hline Çilek & 0.16 & 2.81 & 0.12 & 1.01 & - & - & 0.11 & 0.91 \\
\hline Kivi & - & - & 0.14 & 1.17 & 0.05 & 0.21 & 0.05 & 0.42 \\
\hline Erik & - & - & 0.12 & 1.01 & - & - & 0.04 & 0.33 \\
\hline Şeftali & - & - & - & - & 0.05 & 0.21 & 0.01 & 0.08 \\
\hline Ayva & - & - & 0.03 & 0.25 & - & - & 0.01 & 0.08 \\
\hline Yulaf & 0.21 & 3.69 & 0.03 & 0.25 & - & - & 0.11 & 0.91 \\
\hline Yonca & 0.45 & 7.91 & 0.28 & 2.35 & 0.08 & 0.33 & 0.31 & 2.57 \\
\hline Yulaf + Silaj misır & 0.30 & 5.27 & 0.32 & 2.69 & - & - & 0.23 & 1.91 \\
\hline İşlenmeyen arazi & 0.81 & 14.24 & 0.88 & 7.38 & 1.41 & 5.90 & 0.98 & 8.13 \\
\hline İşletme arazisi & 5.69 & 100.00 & 11.92 & 100.00 & 23.88 & 100.00 & 12.05 & 100.00 \\
\hline
\end{tabular}

***: \%1 düzeyinde istatistiki olarak anlamlıdır

İşletme yöneticilerinin kimyasal gübre ve ilaç kullanımına ilişkin görüşleri incelendiğinde, ilk sırada 4.31 skorla "Ürün verimini koruyacak şekilde gübre ve ilaç kullanımını azaltmak isterim” görüşü yer almaktadır. Bunu üreticilerin "Boş gübre ve ilaç ambalajlarını köy merkezinde uygun bir alan gösterilirse oraya bırakırım" (4.09) ve "Boş gübre ve ilaç ambalajlarının depozitolu olarak iade edilmesi imkânının olmasını isterim" (4.09) görüşleri takip etmektedir.

Üreticilerin en az katıldıkları görüşler; 2.71 skorla "Komşu üreticilerin yanlış gübre ve ilaç kullanımı arazime zarar verir", 2.94 skorla "Organik gübreler de kimyasal gübreler kadar etkilidir” ve 3.06 skorla "Gübre ve ilaçlar sulamayla birlikte yer altı sularına karışır" ifadeleri olmaktadır. İşletme büyüklük grupları arttıkça, gübre ve ilaç kullanımıyla ortaya çıkacak zararlı etkilere karşı gösterilen hassasiyetin de arttığı tespit edilmiştir $(\mathrm{P}<0.01)$ (Çizelge 3). Araştırma sonuçlarından hareketle, üreticilerin boş gübre ve ilaç ambalajlarının uygun şekilde imha edilmesi konusunda sorumluluk üstlenmekte istekli oldukları söylenebilir. Bu durum, üreticilerde çevresel duyarlılığın ve çevrenin korunmasıyla ilgili sorumluluk duygusunun uygulamaya yönelik davranış değişiminin sağlanması açısından önemlidir. Manisa ilinde yapılan bir araştırmada, üreticilerin \%40.1'i bazı pestisitlerin kalıntı bırakabileceğini, \%26.6'sı pestisit kalıntılarının yıkanmayla kaybolacağını, \%21.6'sı ise kalıntı bırakmayacağını belirtmiş̧ir (Erdil ve Tiryaki, 2020). 
Çizelge 3. Üreticilerin gübre ve ilaç uygulamaları konusundaki görüşleri

Table 3. Farmers' points of views on fertilizer and pesticide applications

\begin{tabular}{|c|c|c|c|c|c|}
\hline & 1. grup & 2. grup & 3. grup & $\begin{array}{l}\text { İşletmeler } \\
\text { ortalamas1 }\end{array}$ & $\begin{array}{r}\text { Önem } \\
\text { sirasi } \\
\end{array}$ \\
\hline $\begin{array}{l}\text { Ürün verimini koruyacak şekilde gübre ve ilaç kullanımını } \\
\text { azaltmak isterim }\end{array}$ & 4.09 & 4.51 & 4.48 & 4.31 & 1 \\
\hline $\begin{array}{l}\text { Boş gübre ve ilaç ambalajlarını köy merkezinde uygun bir } \\
\text { alan gösterilirse oraya bırakırım }\end{array}$ & 3.70 & 4.35 & 4.48 & 4.09 & 2 \\
\hline $\begin{array}{l}\text { Boş gübre ve ilaç ambalajlarının depozitolu olarak iade } \\
\text { edilmesi imkânının olmasını isterim }\end{array}$ & 3.63 & 4.41 & 4.55 & 4.09 & 2 \\
\hline $\begin{array}{l}\text { Uzmanlar tarafindan gübreleme ve ilaçlama konusunda } \\
\text { bilgilendirilmeve ihtiyac duyuyorum }\end{array}$ & 388 & 414 & 426 & 405 & 3 \\
\hline Gübre ve ilaçlar etkin kullandığında verimde kayıp olmaz & $\begin{array}{l}3.00 \\
3.86\end{array}$ & 4.24 & $\begin{array}{l}4.20 \\
3.87\end{array}$ & 3.97 & 4 \\
\hline $\begin{array}{l}\text { Boş gübre ve ilaç ambalajlarını ilçe merkezinde uygun bir } \\
\text { alan gösterilirse oraya bırakırım }\end{array}$ & 3.51 & 4.22 & 4.16 & 3.88 & 5 \\
\hline $\begin{array}{l}\text { Gübre ve ilaçlar bilinçsiz kullanıldığında kalıntıya sebep } \\
\text { olur }\end{array}$ & 3.70 & 3.91 & 3.94 & 3.82 & 6 \\
\hline Gübre ve ilaçlar kanser dâhil birçok hastalığa neden olur & 2.98 & 3.38 & 4.00 & 3.35 & 7 \\
\hline $\begin{array}{l}\text { Gübre ve ilaçlar uygun dozda kullanılırsa kalıntı sorunu } \\
\text { olmaz }\end{array}$ & 3.07 & 3.32 & 3.84 & 3.33 & 8 \\
\hline $\begin{array}{l}\text { Gübre ve ilaçların ürünlerde bıraktığı kalıntılar yıkamayla } \\
\text { yok olmaz }\end{array}$ & 2.79 & 3.51 & 3.77 & 3.25 & 9 \\
\hline $\begin{array}{l}\text { Gübre ve ilaçları doğal çevreye ve yaban hayata zararlı } \\
\text { olabilir }\end{array}$ & 2.63 & 3.32 & 3.68 & 3.09 & 10 \\
\hline Gübre ve ilaclar sulamayla birlikte yer altı sularına karısır & 2.70 & 3.11 & 3.68 & 3.06 & 11 \\
\hline Organik gübreler de kimyasal gübreler kadar etkilidir & 2.49 & 2.76 & 3.97 & 2.94 & 12 \\
\hline $\begin{array}{l}\text { Komşu üreticilerin yanlış gübre ve ilaç kullanımı arazime } \\
\text { zarar verir }\end{array}$ & 2.35 & 2.73 & 3.35 & 2.71 & 13 \\
\hline Toplam skor*** & $45.38^{\mathrm{a}}$ & $51.91^{\mathrm{b}}$ & $56.03^{c}$ & 49.95 & \\
\hline
\end{tabular}

***: \%1 düzeyinde istatistiki olarak anlamlıdır

Üreticilerin gübre ve ilaçların uygulanması öncesinde sergiledikleri önemli davranışlar, işletmeler ortalamasına göre ilaçlama (3.67) ve gübreleme (3.59) konularında teknik yardım alma şeklinde olmuştur. İşletmeler ortalamasına göre, gübreleme ve ilaçlama konusunda gazete, dergi, broşür gibi yayınların takip edilmesi (2.53) ve tarım ilaçlarının çözülme özelliklerine göre seçilmesi (2.56) üreticilerin en az üzerinde durdukları konular olarak tespit edilmiştir. Üreticilerin gübreleme ve ilaçlama öncesi kendilerine teknik anlamda yardım sağlayacak eğitim faaliyetlerine katılım, uzman desteği ve konuyla ilgili yayınların takip edilmesi gibi konulara ilgisini gösteren toplam skor işletme büyüklük gruplarına göre artmaktadır $(\mathrm{P}<0.01)$ (Çizelge 4). Ancak üreticilerin gübre ve ilaçların uygulanması öncesi davranışlarıyla ilgili bir genelleme yapmak gerekirse, bu dönemde üreticilerin henüz yeterli bilince sahip olmadıkları söylenebilir.

Kimyasal gübre ve ilaçların uygulanması esnasında, üretici davranışlarına ait toplam skora göre işletme büyüklük grupları arasında istatistiki olarak anlamlı farklılık vardır $(\mathrm{P}<0.01)$. İşletmeler ortalamasına göre gübreleme ve ilaçlama esnasındaki üretici davranışlarına ilişkin en yüksek skorun 3.87 olması, en önemli aşama olan bu uygulama döneminde de uygulama öncesinde olduğu gibi üreticilerin orta düzeyde duyarlılık gösterdikleri anlaşılmaktadır. Genel olarak üreticilerin sergiledikleri en önemli davranış olan çok rüzgârlı havada ilaçlama yapmama (3.87), ilacın rüzgârla birlikte daha hızlı bir şekilde çevreye yayılmasını önlemek açısından önem taşımaktadır. Gübreleme yaparken eldiven ve koruyucu kıyafet kullanımında gösterilen hassasiyet (3.53), işletmeler ortalamasına göre ikinci sırada yer almaktadır. Üçüncü sıradaki davranış ise hastalık, zararlı ve yabancı otların belirli bir popülasyona ulaştığında ilaç kullanmaya başlanmasıdır (3.37). Bu davranışa ait ortalama skora bakıldığında, araştırma bölgesinde entegre mücadele yöntemlerinin çok fazla tercih edilmediği anlaşılmaktadır (Çizelge 5). Hastalık, zararlı ve yabancı otlarla mücadelede yoğun ilaçlamanın etkili tek yöntem olduğu konusundaki yanlış algı, üretim maliyetini artırdığı gibi insan sağlığına ve çevreye zarar vererek doğal dengenin bozulmasına neden olmaktadır. Adıyaman ilinde yapılan bir araştırmada, üreticilerin \%70.7'sinin rüzgarlı havada ilaçlama yapmadığı tespit edilmiştir (Önen ve ark., 2015). Samsun ilinde yapılan bir araştırmada, hastalık, zararlı ve yabancı ot ortaya çıktığında ilaçlama yapan üreticilerin oranı \%81.3 olarak tespit edilmiştir (Bayraktar ve Boz, 2020). Siirt ilinde yapılan bir araştırmaya göre, üreticilerin sadece \%34'ü zararlının yoğunluğuna bakarak zirai mücadele yapmaktadır (Dilmen ve ark., 2020). 
Çizelge 4. Üreticilerin gübre ve ilaçların uygulanması öncesindeki duyarlılıkları

Table 4. Farmers' sensitivity before the application fertilizers and pesticides

\begin{tabular}{|c|c|c|c|c|c|}
\hline & 1. grup & 2. grup & 3. grup & $\begin{array}{l}\text { İşletmeler } \\
\text { ortalaması }\end{array}$ & $\begin{aligned} \text { Önem } \\
\text { siras1 } \\
\end{aligned}$ \\
\hline $\begin{array}{l}\text { İlaçlamaya başlamadan önce teknik yardım } \\
\text { alırım }\end{array}$ & 3.45 & 3.64 & 4.10 & 3.67 & 1 \\
\hline $\begin{array}{l}\text { Gübrelemeye başlamadan önce teknik yardım } \\
\text { alırım }\end{array}$ & 3.30 & 3.62 & 4.10 & 3.59 & 2 \\
\hline $\begin{array}{l}\text { Gübreleme konusundaki eğitimlere katılmaya } \\
\text { özen gösteririm } \\
\text { İlaçlama konusundaki eğitimlere katılmaya }\end{array}$ & 2.60 & 3.24 & 3.54 & 3.02 & 3 \\
\hline $\begin{array}{l}\text { özen gösteririm } \\
\text { İ/İlçe Tarım ve Orman Müdürlüğü teknik } \\
\text { elemanlarının önerilerine göre gübreleme ve }\end{array}$ & 2.51 & 3.16 & 3.61 & 2.98 & 4 \\
\hline ilaçlama yaparım & 2.46 & 2.73 & 3.30 & 2.75 & 5 \\
\hline $\begin{array}{l}\text { Gübre seçimini toprak analizine göre yaparım } \\
\text { Illac secerken, toprakta ve suda çabuk }\end{array}$ & 1.88 & 3.14 & 3.81 & 2.73 & 6 \\
\hline $\begin{array}{l}\text { parçalanmasına dikkat ederim } \\
\text { Gübreleme ve ilaçlama konusunda gazete, }\end{array}$ & 2.20 & 2.67 & 3.10 & 2.56 & 7 \\
\hline $\begin{array}{l}\text { dergi, broşür gibi yayınları takip ederim } \\
\text { Toplam skor*** }\end{array}$ & $\begin{array}{r}1.93 \\
20.33^{\mathrm{a}}\end{array}$ & $\begin{array}{r}2.76 \\
24.96^{\mathrm{b}}\end{array}$ & $\begin{array}{r}3.35 \\
28.91^{\mathrm{c}}\end{array}$ & $\begin{array}{r}2.53 \\
23.83\end{array}$ & 8 \\
\hline
\end{tabular}

***: \%1 düzeyinde istatistiki olarak anlamlıdır

Çizelge 5. Üreticilerin gübre ve ilaç uygulamaları esnasındaki duyarlılıkları

Table 5. Farmers' sensitivity during the applications of fertilizers and pesticides

\begin{tabular}{|c|c|c|c|c|c|}
\hline & 1. grup & 2. grup & 3. grup & $\begin{array}{l}\text { İşletmeler } \\
\text { ortalaması }\end{array}$ & $\begin{array}{r}\text { Önem } \\
\text { sirasi }\end{array}$ \\
\hline Aşırı rüzgârlı havada ilaçlama yapmam & 3.82 & 3.61 & 4.27 & 3.87 & 1 \\
\hline Gübrelemede eldiven ve koruyucu kiyafet & & & & & \\
\hline kullanırım & 3.19 & 3.54 & 4.13 & 3.53 & 2 \\
\hline $\begin{array}{l}\text { Hastalık, zararlı ve yabancı otlar belirli bir } \\
\text { popülasyona geldiğinde ilaç kullanmaya }\end{array}$ & & & & & \\
\hline başlarım & 3.01 & 3.55 & 3.83 & 3.37 & 3 \\
\hline $\begin{array}{l}\text { İlaçlama yaparken ambalajdaki etiket bilgisine } \\
\text { göre doz ayarlaması yaparak gereğinden fazla }\end{array}$ & & & & & \\
\hline ilaç kullanmam & 2.68 & 3.55 & 4.10 & 3.29 & 4 \\
\hline İlaçlamada eldiven ve koruyucu kiyafet & & & & & \\
\hline kullanırım & 2.64 & 3.55 & 4.03 & 3.25 & 5 \\
\hline $\begin{array}{l}\text { Gübreleme ve ilaçlamadan sonra hasada kadar } \\
\text { olan süreyi dikkate alırım }\end{array}$ & 2.54 & 3.55 & 4.10 & 3.23 & 6 \\
\hline $\begin{array}{l}\text { Toprakta yıkanma sonucu içme suyunda ve } \\
\text { akarsulardaki nitrat miktarında artış olmamas } \\
\text { için yüksek düzeyde azotlu gübreleme }\end{array}$ & & & & & \\
\hline yapmam & 2.86 & 3.22 & 3.61 & 3.15 & 7 \\
\hline Zararlıyı görmeden ilaç kullanmaya başlamam & 3.09 & 3.00 & 3.27 & 3.11 & 8 \\
\hline Her yıl aynı gübre çeşidini kullanmam & 2.75 & 3.11 & 3.35 & 3.01 & 9 \\
\hline $\begin{array}{l}\text { Gübre ve ilaç uyguladığım alan ile su } \\
\text { kaynakları arasında güvenli bir mesafe }\end{array}$ & & & & & \\
\hline bırakırım & 2.04 & 2.78 & 3.55 & 2.63 & 10 \\
\hline Toplam skor*** & $28.62^{\mathrm{a}}$ & $33.46^{\mathrm{b}}$ & $38.24^{\mathrm{c}}$ & 32.44 & \\
\hline
\end{tabular}

***: \%1 düzeyinde istatistiki olarak anlamlıdır

Gübreleme ve ilaçlama sonrası boş ambalajların imha edilmesinde uygun olmayan yöntemlerin kullanılması, insanlar başta olmak üzere bütün canlılara zarar vermektedir. Araştırmada, işletmeler ortalamasına göre boş ambalajları yakarak imha etme (3.33) ve tarımsal atıkları birbirleriyle reaksiyona girmeyecek şekilde yok etme (3.22), gübreleme ve ilaçlama sonrası gösterilen en önemli davranışlar olarak tespit edilmiştir. Boş ambalajların poşetlenerek çöp kutusuna atılması (2.88) da, işletmeler ortalamasına göre uygulama sonrasındaki yaygın üretici davranışları arasında yer almaktadır. Boş ambalajları; yakarak imha etme $(\mathrm{P}<0.01)$, birbirleriyle reaksiyona 
girmeyecek şekilde yok etme $(\mathrm{P}<0.01)$, poşetleyerek çöp kutusuna atma $(\mathrm{P}<0.01)$, düzensiz bir şekilde çevreye atma $(\mathrm{P}<0.05)$ ve yıkayıp yeniden kullanma $(\mathrm{P}<0.01)$ davranışları yönünden işletme büyüklük grupları itibariyle istatistiki olarak anlamlı farklılıklar vardır (Çizelge 6). Türkiye'nin farklı bölgelerinde yapılan araştırmalara göre, üreticilerin boş ilaç ambalajlarını kendi yöntemleriyle imha etmesi ya da rastgele çevreye atması yaygın davranışlardır. Antalya ilinde yapılan bir araştırmada, ilaçlama sonrası boş ambalajların yakılması (\%55) ve çöpe atılması (\%26.2) en önemli davranışlar olmakla birlikte, boş ilaç ambalajlarını toprağa gömen $(\% 10)$, çevreye atan (\%8.5) ve yeniden kullanan (\%0.3) üreticilerin de olduğu tespit edilmiştir (Akar ve Tiryaki, 2018). Samsun ilinde yapılan bir araştırmada ise, üreticilerin \%48.2'sinin ilaçlama sonrası boş ambalajları çöpe attığı, \%45.5'inin yaktığı, \%4.5'inin yeniden kullandığı, \%1.8’inin depoladığı ortaya konulmuştur (Bayraktar ve Boz, 2020).

Çizelge 6. Gübre ve ilaç uygulamaları sonrasında boş ambalajların imha edilmesi

Table 6. Disposing of empty packages after applications of fertilizers and pesticides

\begin{tabular}{|c|c|c|c|c|}
\hline & 1. grup & 2. grup & 3. grup & $\begin{array}{c}\text { İşletmeler } \\
\text { ortalaması }\end{array}$ \\
\hline Yakarak imha etme*** & $2.96^{\mathrm{a}}$ & $3.41^{\mathrm{b}}$ & $3.90^{\mathrm{c}}$ & 3.33 \\
\hline Birbirleriyle reaksiyona girmeyecek şekilde atma*** & $2.75^{\mathrm{a}}$ & $3.24^{\mathrm{a}}$ & $4.06^{\mathrm{b}}$ & 3.22 \\
\hline Posetleyerek cöp kutusuna atma*** & $3.07^{\mathrm{a}}$ & $2.86^{\mathrm{b}}$ & $2.55^{\mathrm{b}}$ & 2.88 \\
\hline Düzensiz bir şekilde cevreye atma** & $1.70^{\mathrm{a}}$ & $1.51^{\mathrm{b}}$ & $1.48^{\mathrm{b}}$ & 1.59 \\
\hline Yıkayıp yeniden kullanma*** & $1.30^{\mathrm{a}}$ & $1.22^{\mathrm{a}}$ & $1.00^{\mathrm{b}}$ & 1.20 \\
\hline
\end{tabular}

**: \%5 ve ***: \%1 düzeyinde istatistiki olarak anlamlıdır

\section{Sonuç}

Kimyasal gübre ve tarım ilacı kullanımı, ekonomik ve çevresel açıdan konvansiyonel tarımın en kritik yönlerinden birini teşkil etmektedir. Gerek ülkelerin tarım politikalarındaki eksik uygulamalar gerekse üreticilerin duyarsız yaklaşımları, geçmişte olduğu gibi gelecekte de vazgeçilmez bir sektör olan tarımın sürdürülebilirliğini tehdit eden ve sürekli tartışılan bir alan haline getirmiştir. Bitkisel üretimde yanlış gübreleme ve ilaçlamanın; insan sağlığı, toprak ve su kaynakları ile biyolojik çeşitliliğe yönelik zararlı etkilerini ortaya koyan araştırmaların önemi büyüktür. Zonguldak ilinde yapılan bu araştırma sonuçlarına göre, konvansiyonel meyvecilik yapan işletmelerde kimyasal gübre ve tarım ilacı kullanımının, çevresel etkileri konusunda üreticilerin genel olarak orta düzeyde bilince sahip oldukları görülmektedir. Özellikle birinci gruptaki işletmeler, kimyasal mücadeleye başlamadan önce hastalık ve zararlıların belirli bir popülasyona gelmesinin gerekliliği konusunda çok fazla özen göstermemektedir. Gereğinden fazla yapılan yoğun ilaçlamaya dayalı mücadele şekli toprak, su ve havayı kirletmektedir. Kimyasal gübre ve ilaçların neden olduğu olumsuzlukların minimum seviyeye indirilmesi konusunda, il ve ilçe Tarım ve Orman Müdürlükleri ile üniversiteler tarafından belirli aralıklarla ve birbirleriyle koordineli olarak eğitim faaliyetlerinin artırılması gerekir. Eğitimlerde, ilaçlama dışındaki entegre mücadele yöntemlerine de ağırlık verilerek çevreyle uyumlu alternatif yöntemlerin yaygınlaştırılması sağlanmalıdır. Bu eğitim faaliyetlerinde, mutlaka bitki koruma ve güvenli gıda konusunda uzman teknik elemanlardan yararlanılmasına önem verilmelidir. Söz konusu eğitim faaliyetleriyle, insan sağlığı ve çevrenin korunması konusunda üretici bilinci ve çevre korumaya karşı sorumluluk duygusu güçlendirilmelidir. Önerilen yöntemlerin üreticiler tarafından ne oranda yerine getirildiğinin denetlenmesi, eğitimlerin etkisinin ve başarısının artırılması bakımından önemlidir.

Araştırma sonuçları, üreticilerin çevre koruma konusunda olumlu tutum sergilediklerini, ancak bu durumun üreticilerin gübre ve ilaçların uygulama öncesi, uygulama esnası ve uygulama sonrasındaki davranışlarına net bir şekilde yansımadığı anlaşılmaktadır. Üreticiler gübreleme ve ilaçlama esnasında koruyucu malzeme kullanımında nispeten dikkatli olmalarına rağmen, konuyla ilgili hassasiyetin tam olarak oluştuğu söylenemez. Bu nedenle koruyucu malzeme olmadan uygulama yapıldığında, üreticilerin karşılaşacakları olumsuzluklara yönelik sağlık kuruluşlarından destek alınarak geniş katılımlı seminerler düzenlenmelidir. Ayrıca gübre ve ilaç satışının yapıldığı yerlerde üreticilerin dikkatini çekecek şekilde afişler asılmalı, gübreleme ve ilaçlama yöntemleri ile koruyucu malzeme kullanımı konusunda hazırlanan broşürler dağıtılmalıdır. Gübreleme ve ilaçlama başta olmak üzere, tüm tarımsal uygulamalarla ilgili gerekli çalışmaların doğru şekilde yapılmasının ekonomik, sosyal ve çevresel faydalarına yönelik yapılacak kamu spotları da bu anlamda etkili olacaktır. Kimyasal gübre ve ilaç satışının daha kontrollü yapılmasını sağlayacak uygulanabilir bir denetim sisteminin kurulmasıyla, bu uygulamalara yönelik objektif bir sınırlandırma sistemi de getirilmiş olacaktır. Gübrelemede toprak analizi şartının getirilmesi, ilaçlamada ise reçetelendirme sistemine geçilmesi ve buna yönelik yasal düzenlemelerin yapılması etkili bir denetim sisteminin oluşturulması açısından önemli bir gereklilik olarak düşünülmelidir. Aynı zamanda gübre ve ilaç satışında görevli personele yönelik düzenlenecek eğitim programları, çevresel duyarlılık konusunda üreticilerin doğru karar vermelerini sağlayacaktır. 
Üreticilerin gübre ve ilaçlama sonrası boş ambalajları uygun yöntemlerle imha etmemeleri, başta insan olmak üzere bütün canlılar için büyük risk oluşturmaktadır. Araştırmada, üreticilerin önemli bir kısmının köy merkezinde uygun bir yer temin edilmesi halinde, boş gübre ve ilaç ambalajlarını güvenliği sağlanmış bu yere bırakma konusunda istekli oldukları, ancak böyle bir imkân olmadığı için ambalajların çoğunlukla yakılarak imha edildiği tespit edilmiştir. Dolayısıyla yerel yönetim ve diğer ilgili kurumlar tarafından, gübre ve ilaç uygulaması sonrası ortaya çıkan ambalajlar için öncelikle pilot olarak seçilecek köylerde özel atık toplama alanları oluşturulmalıdır. Böylece seçilen köylerde uygulamadan kaynaklanan eksikler kısa zamanda tespit edileceği gibi, daha geniş alanlar için uygulanabilir bir atık yönetimi planı da hazırlanmış olacaktır. Araştırma alanında gübre ve ilaç ambalajlarının imha edileceği ortamın sağlanmasıyla birlikte, ambalajların imha edilmesi konusunda tam bir bilinçlendirme sağlanana kadar üreticilerin belli aralıklarla bilgilendirilmelerine devam edilmelidir. Bu noktada eğitim çalışmaları ve denetimler faydalı olabileceği gibi, etkileme gücü yüksek olan önder üreticilerden de yardım alınması atık yönetiminde başarıyı artıracaktır.

\section{Kaynaklar}

Akar, Ö., Tiryaki, O., 2018. Antalya ilinde üreticilerin pestisit kullanımı konusunda bilgi düzeyi ve duyarlılıklarının araştırılması. Süleyman Demirel Üniversitesi Ziraat Fakültesi Dergisi, 13(1): 60-70.

Akbaba, B.Z., 2010. Adana ili turunçgil yetiştiriciliği ve insektisit kullanımının değerlendirilmesi. Yüksek lisans tezi, Çukurova Üniversitesi Fen Bilimleri Enstitüsü, 80s, Adana.

Atılgan, A., Coşkan, A., Saltuk, B., Erkan, M., 2007. Antalya yöresindeki seralarda kimyasal ve organik gübre kullanım düzeyleri ve olası çevre etkileri. Ekoloji Dergisi, 15(62): 37-47.

Aydın, B., Öztürk, O., Özer, S., Çebi, Ü., Özkan, E., 2019. Tarımsal uygulamalarda üreticilerin çevre algısının analizi: Edirne ili örneği. Türk Tarım ve Doğa Bilimleri Dergisi 6(4): 851-858.

Bayraktar, A., Boz, İ., 2020. Samsun ili Çarşamba ilçesinde çiftçilerin tarımsal mücadele ilaçları kullanımında çevreye karşı tutum ve davranışları. Türk Tarım-Gıda Bilim ve Teknoloji Dergisi, 8(2): 392-398.

Çelik, A., Karakaya, E., 2017. Bingöl ili Adaklı ilçesi elma üreticilerinin tarımsal ilaç kullanımında bilgi tutum ve davranışlarının değerlendirilmesi ve ekonomik analizi. Türk Tarım ve Doğa Bilimleri Dergisi, 4(2): 119-129.

Demircan, V., Yılmaz, H., 2005. Isparta ili elma üretiminde tarımsal ilaç kullanımının çevresel duyarlılık ve ekonomik açıdan analizi. Ekoloji, 14(57): 15-25.

Dilmen, H., Pala, F., Dilmen, M.Ö., 2020. Antep fistığı (Pistacia vera L.) üreticilerinin tarımsal mücadele konusundaki bilgi düzeylerinin belirlenmesi: Türkiye, Siirt ili örneği. Türkiye Tarımsal Araştırmalar Dergisi, 7(1): $1-8$.

Erbek, E., Özyörük, A., Arslan, Ü., 2018. Bursa ili Gürsu ve Kestel ilçelerindeki meyve üreticilerinin pestisit kullanımına yönelik tutum ve davranışlarının belirlenmesi. Bursa Uludağ Üniversitesi Ziraat Fakültesi Dergisi, 32(2): 69-76.

Erdil, M., Tiryaki, O., 2020. Manisa ilinde çiftçilerin tarım ilaçları kullanımı konusundaki bilinç düzeyi ve duyarlılıklarının araştırılması. Çanakkale Onsekiz Mart Üniversitesi Fen Bilimleri Enstitüsü Dergisi, 6(1): 81-92.

Erdoğan, O., Tohumcu, E., Baran, M.F., Gökdoğan, O., 2017. Adıyaman ili badem üreticilerinin zirai mücadele uygulamalarının değerlendirilmesi. Türk Tarım-Gıda Bilim ve Teknoloji Dergisi, 5(11): 1414-1421.

Eryılmaz, G.A., Kılıç, O., 2018. Türkiye'de sürdürülebilir tarım ve iyi tarım uygulamaları. Kahramanmaraş Sütçü İmam Üniversitesi Tarım ve Doğa Dergisi, 21(4): 624-631.

Günden, C., Miran, B., 2008. Yeni çevresel paradigma ölçeğiyle çiftçilerin çevre tutumunun belirlenmesi: İzmir ili Torbalı ilçesi örneği. Ekoloji, 18(69): 41-50.

Kılıç, B., Uzundumlu, A.S., Tozlu, G., 2018. Fındık üretiminde kimyasal ilaç kullanımının çevresel duyarlılık yönünden incelenmesi: Giresun ili örneği. Türk Tarım ve Doğa Bilimleri Dergisi, 5(4): 396-405.

Kızılaslan, H., Kızılaslan, N., 2005. Çevre konularında kırsal halkın bilinç düzeyi ve davranışları (Tokat ili Artova ilçesi örneği). ZKÜ Sosyal Bilimler Dergisi, 1(1): 67-89.

Kızıloğlu, R., Kızılaslan, N., 2017. Kahramanmaraş ili Merkez ilçe kırsalında çiftçilerin gübre kullanım durumu. Türk Tarım-Gıda Bilim ve Teknoloji Dergisi, 5(1): 18-23.

Kurtaslan, T., Oruç, E., Çiçek, A., 2000. Tokat ilinde çiftçilerin çevre sorunları konusundaki bilgi ve bilinç düzeyleri, konuya ilişkin yaklaşımlarının değerlendirilmesi. IV. Ulusal Tarım Ekonomisi Kongresi, 6-8 Eylül, Tekirdağ.

Oğuz, C., Direk, M., Yiğit, F., 2000. Konya ilinde elma üreticilerinin tarım ilacı kullanımı ve çevresel etkileri. IV. Ulusal Tarım Ekonomisi Kongresi, 6-8 Eylül, Tekirdağ.

Önen, C., Avcı, S., Güneş, G., 2015. Çiftçilerin tarım ilaçlamasında kullandığı koruyucu sağlık önlemleri. Türkiye Halk Sağlığı Dergisi, 13(2): 147-154.

Özcan, Z., Tongur, S., 2019. Pestisitlerin toksisitesinin lepidium sativum test moduyla çevre ve insan sağlığ1 açısından değerlendirilmesi. Ulusal Çevre Bilimleri Araştırma Dergisi, 2(4): 144-150. 
Peker, A.E., 2012. Konya ili domates üretiminde tarımsal ilaç kullanımına yönelik çevresel duyarlılık analizi. Iğdır Üniversitesi Fen Bilimleri Enstitüsü Dergisi, 2(1): 47-54.

Sayın, B., Bayav, A., Beşen, T., Karamürsel, D., Çelikyurt, M., Emre, M., Kuzgun, M., Yılmaz, Ş., Arslan, S., 2020. Üreticilerin biyolojik ve biyoteknik mücadele uygulamalarına bakışı ve çevre duyarlılıklarının belirlenmesi. Kahramanmaraş Sütçü İmam Üniversitesi Tarım ve Doğa Dergisi, 23(2): 453-466.

Sönmez, İ., Kaplan, M., Sönmez, S., 2008. Kimyasal gübrelerin çevre kirliliği üzerine etkileri ve çözüm önerileri. Batı Akdeniz Tarımsal Araştırma Enstitüsü Derim Dergisi, 25(2): 24-34.

TÜİK, 2020. Bitkisel Üretim İstatistikleri. https://biruni.tuik.gov.tr/medas/?kn=92\&locale=tr (Erişim tarihi: 15 Ekim 2020).

Yamane, T., 1967. Elemantary Sampling Theory. Printice Hall Inc. Englewood Cliffs, Nt. 